\title{
Update on laparoscopic/robotic kidney transplant: a literature review
}

This article was published in the following Dove Press journal:

Transplant Research and Risk Management

7 September 2013

Number of times this article has been viewed

\author{
Bulang $\mathrm{He}^{1,2}$ \\ Jeffrey M Hamdorf² \\ 'Liver and Kidney Transplant Unit, \\ Sir Charles Gairdner Hospital, \\ Perth, WA, Australia; ${ }^{2}$ School of \\ Surgery, The University of Western \\ Australia, Perth,WA, Australia
}

\begin{abstract}
Aims: The aim of this paper was to review the current status of laparoscopic/robotic kidney transplant and evaluate its feasibility and safety in comparison with conventional standard "open" kidney transplant.
\end{abstract}

Methods: An electronic search of PubMed, Embase, and the Cochrane library database was performed to identify the papers between January 1980 and June 2013 that reported on laparoscopic/robotic kidney transplantation. The terms "laparoscopic kidney/renal transplant" and "robotic kidney/renal transplant (transplantation)" were used. Cross-referencing was also used to find the further publications. Only English language reports were selected and accepted for descriptive analysis.

Results: A total of 17 papers and abstracts were retrieved. There were two case-control studies of small volume. High-level evidence comparing the safety and efficacy of laparoscopic/ robotic kidney transplant with conventional open kidney transplant was not available at the time of this review.

Conclusion: The limited published data have suggested that laparoscopic/robotic kidney transplant may offer the advantages of less pain, better cosmesis, possible shorter hospital stay, and fewer wound complications, without compromising graft function. Accordingly, some immunosuppressive agents, such as sirolimus, might be able to be commenced earlier, after laparoscopic/robotic kidney transplant. The techniques are various at this early stage. A uniformed operative technique may be established in the near future. With refinement of laparoscopic devices, this technique may be widely employed. Further studies will be needed to demonstrate the advantages of laparoscopic/robotic kidney transplant over the conventional open kidney transplant.

Keywords: laparoscopic surgery, robotic surgery

\section{Introduction}

Over the last three decades, laparoscopic surgery has rapidly expanded in clinical practice, replacing open surgical procedures in a number of areas of abdominal surgery. The first laparoscopic appendectomy was performed in 1981, and a series of successful laparoscopic cholecystectomy procedures followed in due course..$^{2-4}$ Laparoscopic surgical techniques have now been incorporated into surgical practice and training programs. It is well recognized that laparoscopic surgery has advantages over open surgery, related to its use of smaller incision, less analgesia, quicker recovery, and shorter hospital stay. Surgeons continue to promote the evolution of laparoscopic surgery and to employ it in complex surgery, and the availability of information on the World Wide Web has led patients to demand laparoscopic knowledge and skills
Correspondence: Bulang $\mathrm{He}$ Sir Charles Gairdner Hospital, Hospital Avenue, Nedlands, WA 6009, Australia

Tel +6I 893464055

Fax +6I 893467442

Email bulang.he@health.wa.gov.au
Transplant Research and Risk Management 20I3:5 33-39 
from surgeons. In the kidney transplant field, laparoscopic donor nephrectomy has now become the standard of care, provided in most transplant centers since its introduction in 1995. ${ }^{5-9}$ Additionally, over the last 10 years, laparoscopic techniques have been successfully employed for vessel anastomosis with satisfactory results. ${ }^{10-12}$ The demonstration of the reliability of laparoscopic vessel anastomosis has set a benchmark for laparoscopic kidney transplantation, in which vessel anastomosis is usually performed under time pressure. The aim of this paper was to overview the current status of renal transplantation by laparoscopic/robotic surgery.

\section{Methods}

An electronic search of PubMed, Embase, and Cochrane library databases was performed to identify papers published between January 1980 and June 2013 that reported on laparoscopic and robotic kidney transplantation. The terms "laparoscopic kidney/renal transplant" and "robotic kidney/ renal transplant" (transplantation) were used for search. Cross-referencing was also conducted to find further publications on laparoscopic/robotic kidney transplantation. All English language reports were selected and accepted for descriptive analysis, as this is a novel technique.

\section{Results}

\section{Animal models}

There were five papers identified as animal experiments and ex vivo training models. The animal models were established using a porcine "large animal" model. There were four reports of laparoscopic kidney autotransplantation, including both heterotopic and orthotopic transplantation, respectively. Firstly, Meraney et $\mathrm{al}^{13}$ conducted laparoscopic renal autotransplantation in six female pigs in 2001. In this work, a laparoscopic donor nephrectomy was performed on the animals' left side. Then, the kidney graft was autotransplanted in the left iliac region, with the renal artery and vein anastomosed end-to-side with their iliac counterparts. Hypothermic renal perfusion was established, via cannulation to the renal artery and perfusion with ice-cold heparinized Ringer's solution, during the venous anastomosis. The graft warm ischemia time lasted from 3 to 8 minutes (mean 5.1 minutes). The time for renal artery anastomosis was 31 (27-35) minutes and for the renal vein, was 33 (22-46) minutes. Five of six transplanted kidney grafts functioned satisfactorily, yielding a mean serum creatinine $(\mathrm{Cr})$ level of $1.6 \mathrm{mg} / \mathrm{dL}$ (1.0-1.9 mg/dL). Histopathology showed a normal architecture, without evidence of acute tubular necrosis. One graft failure occurred due to vessel thrombosis.
Most recently, He et al ${ }^{14-16}$ published a different preclinical technique of laparoscopic kidney autotransplant in a pig model. The laparoscopic donor nephrectomy was performed on the left side, and subsequently, the left kidney was transplanted at the orthotopic location, with renal artery and vein anastomosed in an end-to-end fashion. The study was conducted in three stages. In stage 1, the transplanted kidney was observed for only 4 hours while the pig remained under anesthesia. In stage 2, the contralateral right kidney was allowed to remain functioning in situ while the pigs recovered from surgery and were observed, for 1 week, before planned euthanasia. In stage 3, the contralateral right kidney was rendered nonfunctional by complete ligation of the ureter at the time of the transplant surgery. The pigs were recovered and observed for 4 weeks. The transplanted kidney grafts demonstrated immediate function. The serum $\mathrm{Cr}$ was $1.3 \mathrm{mg} / \mathrm{dL}$ presurgery, $2.54 \mathrm{mg} / \mathrm{dL}$ on day $7,1.44 \mathrm{mg} / \mathrm{dL}$ on day 14 , and $1.87 \mathrm{mg} / \mathrm{dL}$ on day 28 . The hemoglobin $(\mathrm{Hb})$ was $108.5 \mathrm{~g} / \mathrm{L}$ presurgery, $121 \mathrm{~g} / \mathrm{L}$ immediately after surgery, $117 \mathrm{~g} / \mathrm{L}$ on day 7, $103 \mathrm{~g} / \mathrm{L}$ on day 14 , and $106 \mathrm{~g} / \mathrm{L}$ on day 28 . There were no complications, such as hemorrhage or urine leakage. All the pigs recovered normal activity after 24-48 hours, but one died after extubation. At necropsy, the cause of death was found to be laryngospasm. It was concluded that orthotopic kidney transplant performed by laparoscopic technique is feasible and safe in the preclinical pig model: immediate graft function was achieved by laparoscopic vessel anastomosis.

In addition, Khanna and Horgan ${ }^{17}$ reported a training model of ex vivo robotic kidney transplantation using the porcine kidney and iliac vessels. It was emphasized that the vascular anastomotic time was reduced significantly over the time of training. These researchers have no doubt facilitated the transition of laparoscopic/robotic kidney transplant to the human.

\section{Human kidney transplant}

A total of eleven papers and abstracts were identified. Of these, five described laparoscopic kidney transplantation, whereas six presented robotic kidney transplantation. Case-control studies were identified in two papers. There were only case or case-series reports for robotic kidney transplant. The details are listed in Tables 1 to 4 .

\section{Laparoscopic technique}

In 2009, Rosales et a $1{ }^{18}$ performed the first laparoscopic kidney transplant from a living donor. The recipient was positioned in the left lateral decubitus position. A $7 \mathrm{~cm}$ Pfannenstiel incision 
Table I Demographic data of patients and results in laparoscopic kidney transplant

\begin{tabular}{|c|c|c|c|c|c|c|c|c|c|c|c|c|}
\hline \multirow[t]{2}{*}{ Year } & \multirow[t]{2}{*}{ Author } & \multirow{2}{*}{$\begin{array}{l}\text { No of } \\
\text { cases }\end{array}$} & \multicolumn{2}{|l|}{ Donor } & \multicolumn{2}{|c|}{ Recipient } & \multirow{2}{*}{$\begin{array}{l}\text { OT } \\
(\mathrm{min})\end{array}$} & \multirow{2}{*}{$\begin{array}{l}\text { VAT } \\
(\mathrm{min})\end{array}$} & \multirow{2}{*}{$\begin{array}{l}\text { WIT } \\
(\min )\end{array}$} & \multirow{2}{*}{$\begin{array}{l}\text { CIT } \\
\text { (hr/min) }\end{array}$} & \multirow{2}{*}{$\begin{array}{l}\text { Blood loss } \\
(\mathrm{mL})\end{array}$} & \multirow{2}{*}{$\begin{array}{l}\text { LOH } \\
\text { (days) }\end{array}$} \\
\hline & & & Category & $\begin{array}{l}\text { Age } \\
\text { (years) }\end{array}$ & $\begin{array}{l}\text { Age } \\
\text { (years) }\end{array}$ & $\begin{array}{l}\text { BMI } \\
\text { (weight }[\mathrm{kg}] / \\
\text { height }^{2}\left[\mathrm{~m}^{2}\right] \text { ) }\end{array}$ & & & & & & \\
\hline 2010 & $\begin{array}{l}\text { Rosales } \\
\text { et al }{ }^{18}\end{array}$ & 1 & Live & NA & 69 & 22 & 240 & 53 & 53 & $182 \mathrm{~min}$ & NA & NA \\
\hline 2011 & Modi $^{19}$ & 4 & Deceased & 64.3 & 37.2 & 21.4 & $\begin{array}{l}238 \\
(210-300)\end{array}$ & $\begin{array}{l}65 \\
(60-72)\end{array}$ & $\begin{array}{l}65 \\
(60-72)\end{array}$ & $\begin{array}{l}8.4 \mathrm{hr} \\
(4-14)\end{array}$ & $\begin{array}{l}131 \\
(30-350)\end{array}$ & NA \\
\hline 2012 & Abraham $^{21}$ & 3 & Live & NA & 32.3 & 22.1 & 210 & NA & NA & $55.3 \mathrm{~min}$ & 150 & 7.3 \\
\hline 2013 & Modi $^{20}$ & 72 & Live & NA & 34.4 & 20.5 & $\begin{array}{l}223.8 \\
(160-325)\end{array}$ & $\begin{array}{l}50.3 \\
(37-62)\end{array}$ & $\begin{array}{l}60.3 \\
(47-90)\end{array}$ & $\begin{array}{l}106.1 \mathrm{~min} \\
(26-229)\end{array}$ & $\begin{array}{l}67.8 \\
(35-200)\end{array}$ & NA \\
\hline
\end{tabular}

Abbreviations: BMI, body mass index; CIT, cold ischemia time; hr, hours; LOH, length of hospital stay; min, minutes; NA, not available; OT, operating time; VAT, vascular anastomotic time; WIT, warm ischemia time.

was made with a hand-access device, through which one $11 \mathrm{~mm}$ port was inserted. Three more ports were inserted in the right hemiabdomen. Dissection of the iliac vessels was undertaken via the transperitoneal approach. The renal vein was anastomosed, in end-to-side fashion, to the external iliac vein by using 5-0 uncoated monofilament polypropylene running sutures. In the same fashion, the renal artery was anastomosed to the external iliac artery, using interrupted sutures. Kidney graft hypothermia was maintained by continuous irrigation with cold normal saline. The ureterovesical anastomosis was performed using a modified Taguchi technique. The kidney graft was then placed in the extraperitoneal location by closure of the retroperitoneal window.

Subsequently, Modi et al ${ }^{19,20}$ reported 76 cases of laparoscopic kidney transplant (the first four cases from deceased donors and 72 cases from live kidney donors) using a slightly different technique. The patient was supine and placed in a 20-degree Trendelenburg position. A 6-7 cm incision was made in the iliac fossa or suprapubic region. Four $12 \mathrm{~mm}$ ports were used. The renal vein and artery were anastomosed in an end-to-side fashion to the external iliac vein and artery, respectively, using two separate 5-0 polypropylene running sutures. The ureteroneocystostomy was performed by modified Lich-Gregoir method, using 4-0 polyglactin sutures. The kidney graft was positioned in an extraperitoneal space by closing the retroperitoneal window.
Abraham et $\mathrm{al}^{21}$ presented three cases of laparoscopic kidney transplantation at the Annual Meeting of the American Urology Association, in Atlanta, USA in May, 2012. There were no details of the technique described, but the dissection was done via the intraperitoneal approach, and the kidney graft was placed in the extra peritoneal space by closure of the retroperitoneal window.

\section{Robotic technique}

The first human kidney transplant relying on robotic assistance was conducted via a conventional open incision, by Hoznek et $\mathrm{al}^{22}$ in 2002 . The patient was placed in the supine position, with legs spread and flexed to allow positioning of the surgical instrument cart. The da Vinci ${ }^{\circledR}$ Surgical System (Intuitive Surgical Inc, Sunnyvale, CA, USA) was used, and the robotic instruments were positioned via the open wound at the left iliac fossa. The three-dimensional (3D) 30-degree endoscope was placed in the sagittal plane, at an angle of 45 degrees to the horizontal. Using the robotic device, the vessel dissection and anastomosis were performed as well as the ureteroneocystostomy, in the same fashion as in open transplant surgery.

Eight years later, Giulianotti et $\mathrm{al}^{23}$ reported a robotic kidney transplant in a morbidly obese patient (body mass index [BMI] $41 \mathrm{~kg} / \mathrm{m}^{2}$ ), via a minimally invasive approach. The patient was positioned in a left decubitus position,

Table 2 Comparison of laparoscopic kidney transplant with conventional open kidney transplant

\begin{tabular}{|c|c|c|c|c|c|c|c|c|c|c|}
\hline \multicolumn{2}{|c|}{$\begin{array}{l}\text { No } \\
\text { of cases }\end{array}$} & \multirow[t]{2}{*}{ OT } & \multirow[t]{2}{*}{ VAT } & \multirow[t]{2}{*}{ Blood loss } & \multirow[t]{2}{*}{ DGF } & \multirow[t]{2}{*}{$\begin{array}{l}\text { Wound } \\
(\mathrm{cm})\end{array}$} & \multirow[t]{2}{*}{$\begin{array}{l}\mathrm{Cr} \\
\text { (I month) }\end{array}$} & \multirow[t]{2}{*}{$\begin{array}{l}\mathrm{Cr} \\
\text { (I year) }\end{array}$} & \multirow[t]{2}{*}{ Pain score } & \multirow{2}{*}{$\begin{array}{l}\text { Graft } \\
\text { survival } \\
\text { (I year) }\end{array}$} \\
\hline LKT & OKT & & & & & & & & & \\
\hline 72 & 145 & $\begin{array}{l}\text { LKT }>\text { OKT } \\
(P<0.03)\end{array}$ & $\begin{array}{l}\mathrm{LKT}>\text { OKT } \\
(P<0.03)\end{array}$ & $\begin{array}{l}\text { No } \\
\text { significance }\end{array}$ & $\begin{array}{l}\text { No } \\
\text { significance }\end{array}$ & $\begin{array}{l}\text { LKT:OKT } \\
5.5 \pm 0.8: \\
\text { I } 7.8 \pm 4.6\end{array}$ & $\begin{array}{l}\text { LKT > OKT } \\
(P=0.01)\end{array}$ & $\begin{array}{l}\text { No } \\
\text { difference }\end{array}$ & $\begin{array}{l}\text { LKT }<\text { OKT } \\
(P<0.05)\end{array}$ & $\begin{array}{l}\text { LKT:OKT } \\
87.7 \%: 96.5 \% \\
(P=0.02)\end{array}$ \\
\hline
\end{tabular}

Note: Data from Modi et al. ${ }^{20}$

Abbreviations: Cr, creatinine; DGF, delayed graft function; LKT, laparoscopic kidney transplant; OKT, open kidney transplant; OT, operating time; VAT, vascular anastomotic time. 
Table 3 Demographic data of patients and results, in robotic kidney transplant

\begin{tabular}{|c|c|c|c|c|c|c|c|c|c|c|c|c|}
\hline \multirow[t]{2}{*}{ Year } & \multirow[t]{2}{*}{ Author } & \multirow{2}{*}{$\begin{array}{l}\text { No } \\
\text { of cases }\end{array}$} & \multicolumn{2}{|l|}{ Donor } & \multicolumn{2}{|c|}{ Recipient } & \multirow{2}{*}{$\begin{array}{l}\text { OT } \\
(\mathrm{min})\end{array}$} & \multirow{2}{*}{$\begin{array}{l}\text { VAT } \\
\text { (min) }\end{array}$} & \multirow{2}{*}{$\begin{array}{l}\text { WIT } \\
\text { (min) }\end{array}$} & \multirow{2}{*}{$\begin{array}{l}\text { CIT } \\
\text { (hr) }\end{array}$} & \multirow{2}{*}{$\begin{array}{l}\text { Blood loss } \\
(\mathrm{mL})\end{array}$} & \multirow{2}{*}{$\begin{array}{l}\text { LOH } \\
\text { (days) }\end{array}$} \\
\hline & & & Category & $\begin{array}{l}\text { Age } \\
\text { (years) }\end{array}$ & $\begin{array}{l}\text { Age } \\
\text { (years) }\end{array}$ & $\begin{array}{l}\text { BMI } \\
\text { (weight }[\mathrm{kg}] / \\
\text { height }^{2}\left[\mathrm{~m}^{2}\right] \text { ) }\end{array}$ & & & & & & \\
\hline 2002 & Hoznek $^{22}$ & I & Deceased & 50 & 26 & NA & 178 & 57 & 57 & 26.7 & NA & NA \\
\hline 2010 & Giulianotti ${ }^{23}$ & 1 & Deceased & 47 & 29 & $4 I$ & 223 & 50 & 50 & 11 & NA & 5 \\
\hline 2011 & Boggi ${ }^{26}$ & I & Live & 56 & 37 & 21.9 & 154 & 51 & 51 & NA & NA & 10 \\
\hline 2012 & Bhati ${ }^{24}$ & 10 & $\begin{array}{l}9 \text { live } \\
\text { I deceased }\end{array}$ & NA & 44 & 40.5 & 305 & 49 & 49 & 2.58 & 90 & 6 \\
\hline
\end{tabular}

Abbreviations: BMI, body mass index; CIT, cold ischemia time; hr, hours; LOH, length of hospital stay; min, minutes; NA, not available; OT, operating time; VAT, vascular anastomotic time; WIT, warm ischemia time.

exposing the right flank. The da Vinci System was docked into position on the patient's right side. The surgical incision was only $7 \mathrm{~cm}$ at the periumbilical region, to facilitate the placement of the kidney graft into the body, and a Lap Disc (Ethicon Endosurgery Inc, Blue Ash, OH, USA) was inserted over the incision. Two $12 \mathrm{~mm}$ ports, and two $7 \mathrm{~mm}$ ports were required for the 3-D 30 degree scope, for use by an assistant, and two robotic instruments respectively. The iliac vessel dissection was performed by mobilizing the right colon via a transperitoneal approach. The renal vein and renal artery were anastomosed, in end-to-side fashion, to the external iliac vein and artery, respectively, with running 6-0 Gore-Tex ${ }^{\circledR}$ sutures. The ureteroneocystostomy was done by running a 6-0 Polydioxanone suture. The kidney graft was placed in the intraperitoneal cavity. Furthermore, Dr Bhati, from the same center, presented ten more robotic kidney transplants in obese patients at the American Transplant Congress, in Philadelphia, USA, in 2011, ${ }^{24}$ followed by Oberholzer et al who reported 39 cases of robotic kidney transplant, from the same unit, from June 2009 to December $2011 .{ }^{25}$ As reported by Oberholzer, the surgical site infections were significantly fewer compared with a historical cohort of 28 obese recipients who had conventional open kidney transplantation.

In Europe, Boggi et $\mathrm{al}^{26}$ conducted a robotic kidney transplant from a live donor kidney, using a different technique from that described in the above reports. The recipient was placed in a supine position, with the right flank slightly elevated and the table then tilted 25 degree to the left, with a 15-degree Trendelenburg position. Two $12 \mathrm{~mm}$ ports, one $11 \mathrm{~mm}$ port, and one $8 \mathrm{~mm}$ port were used in this technique. A $7 \mathrm{~cm}$ suprapubic incision was created, and a Lap Disc was employed over the incision, into which one of the two $12 \mathrm{~mm}$ ports was inserted. The da Vinci System was docked into the patient's right side. The dissection of the iliac vessels was done via the intraperitoneal approach. The renal vein and artery were anastomosed in an end-to-side fashion to the common iliac vein and artery, using two half 6-0 expanded polytetrafluoroethylene (ePTFE) running sutures. However, the ureteroneocystostomy was performed via a suprapubic incision, as an open approach. The kidney graft was covered by the pelvic peritoneum and positioned at the extraperitoneal space.

\section{Operation time}

In general, the time taken for laparoscopic kidney transplant surgery was from 210 minutes to 300 minutes, with an average of 238 minutes. The vascular anastomotic time was from 53 to 72 minutes, average 59 minutes. In the case series study by Modi et al, ${ }^{20}$ it was evident that the laparoscopic technique took a longer time than conventional open surgery, and this was also true of the vascular anastomotic time. The reported rate of conversion to an open procedure was 5.6\%. Clearly, the laparoscopic kidney transplant is still in its infancy. We anticipate that

Table 4 Comparison of robotic kidney transplant with open kidney transplant, in obese recipients

\begin{tabular}{|c|c|c|c|c|c|c|c|c|c|}
\hline & $\begin{array}{l}\text { No } \\
\text { of cases }\end{array}$ & $\begin{array}{l}\text { BMI } \\
\text { (weight }[\mathrm{kg}] / \\
\text { height }^{2}\left[\mathrm{~m}^{2}\right] \text { ) }\end{array}$ & $\begin{array}{l}\text { Conversion } \\
\text { rate }\end{array}$ & DGF & $\begin{array}{l}\text { Follow up } \\
\text { (months) }\end{array}$ & $\begin{array}{l}\text { Patient } \\
\text { survival }\end{array}$ & $\begin{array}{l}\text { Graft } \\
\text { survival }\end{array}$ & $\begin{array}{l}\text { Wound } \\
\text { complication }\end{array}$ & $\begin{array}{l}\text { LOH } \\
\text { (days) }\end{array}$ \\
\hline $\begin{array}{l}\text { Robotic } \\
\text { kidney } \\
\text { transplant }\end{array}$ & 39 & $42.6 \pm 7.8$ & $\begin{array}{l}5.1 \% \\
(2 / 39)\end{array}$ & $\begin{array}{l}3.6 \% \\
(1 / 28)\end{array}$ & $\begin{array}{l}6 \\
(28 / 39)\end{array}$ & $\begin{array}{l}100 \% \\
(28 / 28)\end{array}$ & $\begin{array}{l}100 \% \\
(28 / 28)\end{array}$ & $\begin{array}{l}3.6 \% \\
(1 / 28)\end{array}$ & $8.2 \pm 4.5$ \\
\hline Open & 28 & $38.1 \pm 5.4$ & NA & 0 & $28 / 28$ & $100 \%$ & $100 \%$ & $28.6 \%$ & $8.1 \pm 5.3$ \\
\hline $\begin{array}{l}\text { kidney } \\
\text { transplant }\end{array}$ & & $P=0.02$ & & $P=0.99$ & & $(28 / 28)$ & $(28 / 28)$ & $\begin{array}{l}(8 / 28) \\
P=0.02\end{array}$ & $P=0.98$ \\
\hline
\end{tabular}

Note: Data from Oberholzer et al. ${ }^{25}$

Abbreviations: BMI, body mass index; DGF, delay graft function; LOH: length of hospital stay. 
the technique will be modified, and better instruments may also be developed in the near future. It is expected that the surgical time will be reduced to be comparable with that of open surgery or perhaps even quicker than open surgery over time.

The time to complete robotic kidney transplant surgery ranged from 154 minutes to 305 minutes, with an average of 215 minutes; whereas the vascular anastomotic time was from 35 to 58 minutes, with an average of 52 minutes. There was no substantial difference in anastomotic times in comparison with the laparoscopic technique. The conversion rate was $8.6 \%$. However, at this early stage, there has not yet been a randomized, controlled study that has provided high-level evidence.

\section{Recipient outcome and graft function}

There was no surgical mortality in any laparoscopic or robotic kidney transplant recipients. There were no significant differences in blood loss: from $30 \mathrm{~mL}$ to $350 \mathrm{~mL}$ (mean $140 \mathrm{~mL}$ ) in the laparoscopic group and $50 \mathrm{~mL}$ to $200 \mathrm{~mL}$ (mean $90 \mathrm{~mL}$ ) in the open kidney transplant $(P=0.46)$ group. ${ }^{20}$ There was also no significant difference in delayed graft function (DGF) in a case-control study of laparoscopic kidney transplant in comparison with open kidney transplant, in which the 1-year graft survival was $87.7 \%$ versus $96.5 \%$, respectively $(P=0.02) ;{ }^{20}$ the 1 -year patient survival was $98 \%$ versus $96.8 \% .{ }^{20}$ In a case series report of robotic kidney transplantation, the DGF was $3.7 \%$; the patient survival was $100 \%{ }^{25}$

\section{Analgesic consumption}

The visual analogue scores for pain were significantly less in the laparoscopic kidney transplant group when compared with the group that had open kidney transplant $(P<0.05) .{ }^{16-20}$ Giulianotti et $\mathrm{al}^{23}$ have also described that minimal pain was experienced by patients after robotic kidney transplant in comparison with the pain from other surgical techniques. In Boggi's ${ }^{26}$ case report, the pain was described as minimal, and no analgesia was needed after 48 hours following surgery. Apart from the first robotic kidney transplant, all the other laparoscopic/ robotic kidney transplants were performed by minimally invasive approach, with an incision length of $7 \mathrm{~cm}$. Therefore, the pain is anticipated to be less, in comparison with conventional open kidney transplant surgery, for which the incision has been reported as $17.8 \pm 4.6 \mathrm{~cm} .{ }^{20}$ However, at this stage, there has not been a randomized, controlled study that has provided high level evidence regarding analgesia consumption.

\section{Length of hospital stay}

The length of hospital stay was 7.3 days following laparoscopic kidney transplant, while it was $8.2 \pm 4.6$ days
(4-13 days) after robotic kidney transplant. In the case series study $^{25}$ of robotic kidney transplant from the University of Illinois, the recipient BMI was $42.9 \pm 7.8$ weight $(\mathrm{kg}) /$ height $^{2}\left(\mathrm{~m}^{2}\right)$. There was one wound complication. It has been recognized that robotic approach has almost eliminated wound complications in obese patients.

\section{Conclusion}

Complex laparoscopic surgery can be successfully performed after undertaking appropriate training. Whilst the first robotic assisted kidney transplant was done with a conventional open incision, it nevertheless evoked a surgical revolution in kidney transplant. ${ }^{22}$ Undoubtedly, this is a challenging technique, as it took 8 years to see the first case of laparoscopic kidney transplant ${ }^{15}$ following the first robotic kidney transplant. Between 2002 and 2010, only three case reports were found in the literature. However, over the last 2 years, there has been a dramatic increase, with 80 cases of laparoscopic kidney transplant and a further 42 robotic kidney transplants reported. In addition, 16 more robotic kidney transplants were identified in the discussion by Boggi et al, ${ }^{24}$ that were performed at Saint Barnabas Medical Center, New Jersey, USA.

The present studies have demonstrated that laparoscopic/ robotic kidney transplant is feasible and apparently safe, with satisfactory graft function both in large animal models and early human clinical practice. Yet, there is no highlevel evidence of safety and efficacy in the literature at this early stage. However, there was no surgical mortality, and the intraoperative blood loss was $90 \mathrm{~mL}$ on average, with a maximum blood loss of $350 \mathrm{~mL}$. The kidney grafts have functioned immediately after transplantation, and there was no reported graft loss from surgical complications. The conversion to open surgery was 5.5\% during laparoscopic surgery and $7.3 \%$ during robotic transplant in two case-series reports, ${ }^{18,23}$ which is comparable with the conversion rate of $3 \%-6.1 \%$ at the early stage of laparoscopic nephrectomy. ${ }^{27}$ Understandably, this new approach is still in its infancy and should mature over time. It will be expected that randomized, controlled studies will be conducted in the near future, to provide further evidence of the benefit of transplanting recipients using the laparoscopic/robotic technique.

The surgical time and the vessel anastomotic time are slightly longer in robotic/laparoscopic kidney transplant at this early stage. This can be justified, as robotic/laparoscopic kidney transplantation is still a very new technique, and the instruments have not been expressly designed for kidney transplant. However, the 1-year graft function has not been found to be significantly affected by the prolonged vessel 
anastomotic time..$^{20}$ Further, it is expected that the surgical time and anastomotic time will become comparable with those achieved with open surgery, or even shorter, as the technique improves. Adequate training and experience is required before surgeons can consider the offer of this procedure to humans. The animal models are readily available to help meet individual training requirements; success in performing surgery in the live animal model will assure the surgeon's capability to conduct vascular anastomosis under the time pressure of human kidney transplant.

The pain score was found to be significantly lower in laparoscopic kidney transplant, in a case-control study by Modi et al. ${ }^{20}$ The length of hospital stay was 7.3 days and $8.2 \pm 4.6$ days, respectively, in laparoscopic and robotic kidney transplant. ${ }^{20,23}$ A randomized, controlled study should be considered in the near future, to determine the advantages of kidney transplant by laparoscopic/robotic surgical technique.

As a minimally invasive procedure, laparoscopic/ robotic kidney transplant uses a significantly smaller incision than does open kidney transplant. In general, morbidly obese patients exhibit an increased risk of wound infection, requiring prolonged hospital stay. The small incision has been found to reduce the risk of wound infection and other associated complications - Oberholzer et al have found the robotic approach has almost eliminated wound complications in morbidly obese patients. ${ }^{25}$ In addition, a smaller incision may allow for earlier administration of sirolimus (which has been known to be related to increased incidence of wound complications). ${ }^{28}$

From a technical perspective, laparoscopic and robotic kidney transplant are comparable. The average operating time is relative shorter in robotic kidney transplant than in the laparoscopic group, 215 minutes versus 238 minutes, respectively. However, robotic surgery allows for a higher BMI patient. The vessel anastomotic time is shorter using the robotic technique than with the laparoscopic technique. Still, any conclusion could be debated, as it would only be based on a case-series report rather than a controlled study.

In summary, laparoscopic/robotic kidney transplant is a novel approach for kidney transplant. The initial experience has demonstrated that it is feasible and safe and that immediate graft function can be achieved. The technique is highly demanding, and appropriate training is mandatory. The drawback of the robotic technique is its high cost. The facility is not readily available in most transplant units. Nevertheless, laparoscopic devices are widely employed in surgical practice. Further study should be conducted to obtain high-level evidence of laparoscopic/robotic kidney transplant safety and efficacy.

\section{Disclosure}

The authors report no conflicts of interest in this work.

\section{References}

1. Semm K. Endoscopic appendectomy. Endoscopy. 1983;15(2):59-64.

2. Mühe E. Laparoscopic cholecystectomy. Late results. Klin Khir. 1991;(11):10-13. Russian.

3. Ko ST, Airan MC. Review of 300 consecutive laparoscopic cholecystectomies: development, evolution, and results. Surg Endosc. 1991;5(3):103-108.

4. Adams DB, Greene FL. Laparoscopic cholecystectomy: a time for reflection. J S C Med Assoc. 1990;86(12):613-616.

5. Ratner LE, Ciseck LJ, Moore RG, Cigarroa FG, Kaufman HS, Kavoussi LR. Laparoscopic live donor nephrectomy. Transplantation. 1995;60(9):1047-1049.

6. Øyen O, Andersen M, Mathisen L, et al. Laparoscopic versus open living-donor nephrectomy: experiences from a prospective, randomized, single-center study focusing on donor safety. Transplantation. 2005;79(9):1236-1240.

7. Simforoosh N, Basiri A, Tabibi A, Shakhssalim N, Hosseini Moghaddam SM. Comparison of laparoscopic and open donor nephrectomy: a randomized controlled trial. BJU Int. 2005;95(6):851-855.

8. Andersen MH, Mathisen L, Oyen O, et al. Postoperative pain and convalescence in living kidney donors-laparoscopic versus open donor nephrectomy: a randomized study. Am J Transplant. 2006;6(6): 1438-1443.

9. He B, Mitchell A, Delriviere L, et al. Laparoscopic donor nephrectomy. ANZ J Surg. 2011;81(3):159-163.

10. Chung BI, Gill IS. Laparoscopic splenorenal venous bypass for nutcracker syndrome. J Vasc Surg. 2009;49(5):1319-1323.

11. Bruls S, Quaniers J, Tromme P, Lavigne JP, Van Damme H, Defraigne JO. Comparison of laparoscopic and open aortobifemoral bypass in the treatment of aortoiliac disease. Results of a contemporary series (2003-2009). Acta Chir Belg. 2012;112(1):51-58.

12. Hsu TH, Gill IS, Sung GT, Meraney A, McMahon JT, Novick AC. Laparoscopic aortorenal bypass. J Endourol. 2000;14(2):123-131.

13. Meraney AM, Gill IS, Kaouk JH, Skacel M, Sung GT. Laparoscopic renal autotransplantation. $J$ Endourol. 2001;15(2):143-149.

14. He B, Musk GC, Mou L, Waneck GL, Delriviere L. Laparoscopic surgery for kidney orthotopic transplant in the pig model. JSLS. 2013;17(1):126-131.

15. He B, Musk GC, Mou L, Waneck GL, Delriviere L. Laparoscopic kidney orthotopic transplant: preclinical study in the pig model. Transplant Proc. 2013;45(5):1776-1779.

16. He B, Musk GC, Mou L, De Boer B, Delriviere L, Hamdorf J. Laparoscopic surgery for orthotopic kidney transplant in the pig model. J Surg Res. Epub March 26, 2013.

17. Khanna A, Horgan S. A laboratory training and evaluation technique for robot assisted ex vivo kidney transplantation. Int J Med Robot. 2011;7(1):118-122.

18. Rosales A, Salvador JT, Urdaneta G, et al. Laparoscopic kidney transplantation. Eur Urol. 2010;57(1):164-167.

19. Modi P, Rizvi J, Pal B, et al. Laparoscopic kidney transplantation: an initial experience. Am J Transplant. 2011;11(6):1320-1324.

20. Modi P, Pal B, Modi J, et al. Retroperitoneoscopic living-donor nephrectomy and laparoscopic kidney transplantation: experience of initial 72 cases. Transplantation. 2013;95(1):100-105.

21. Abraham G, Das K, Ramaswami K, George D, Abraham J, Thampan O. Laparoscopic live related renal transplantation- a feasible option? J Urol. 2012;187(Suppl 4):e694-e695. 
22. Hoznek A, Zaki SK, Samadi DB, et al. Robotic assisted kidney transplantation: an initial experience. J Urol. 2002;167(4):1604-1606.

23. Giulianotti P, Gorodner V, Sbrana F, et al. Robotic transabdominal kidney transplantation in a morbidly obese patient. Am J Transplant. 2010;10(6):1478-1482.

24. Bhati CS, Jeon H, Tzvetanov I, et al. Hand assisted robotic kidney transplantation in morbidly obese recipients: initial single center experience. Am J Transplant. 2011; 11(1):68-69.

25. Oberholzer J, Giulianotti P, Danielson KK, et al. Minimally invasive robotic kidney transplantation for obese patients previously denied access to transplantation. Am J Transplant. 2013;13(3):721-728.
26. Boggi U, Vistoli F, Signori S, et al. Robotic renal transplantation: first European case. Transpl Int. 2011;24(2):213-218.

27. Keeley FX, Tolley DA. A review of our first 100 cases of laparoscopic nephrectomy: defining risk factors for complications. $\mathrm{Br} J$ Urol. 1998;82(5):615-618.

28. Troppmann C, Pierce JL, Gandhi MM, Gallay BJ, McVicar JP, Perez RV. Higher surgical wound complication rates with sirolimus immunosuppression after kidney transplantation: a matched-pair study. Transplantation. 2003;76(2):426-429.

\section{Publish your work in this journal}

Transplant Research and Risk Management is an international, peerreviewed open access journal focusing on all aspects of transplantation and risk management to achieve optimal outcomes in the recipient improving survival and quality of life. The journal welcomes submitted papers covering original research, basic science, clinical studies, reviews \& evaluations, guidelines, expert opinion and commentary, case reports and extended reports. The manuscript management system is completely online and includes a very quick and fair peer-review system, which is all easy to use. Visit http://www.dovepress.com/ testimonials.php to read real quotes from published authors.

Submit your manuscript here: http://www.dovepress.com/transplant-research-and-risk-management-journal 